\title{
LIFE DISRUPTED AND REGENERATED: COPING WITH THE 'NEW NORMAL' CREATIVE ARTS IN THE TIME OF CORONAVIRUS
}

\author{
Connie Lim Keh Nie* \\ Universiti Malaysia Sarawak, Malaysia \\ Chong-Lee Yow \\ Universiti Malaysia Sarawak, Malaysia \\ Chow Ow Wei \\ Universiti Putra Malaysia, Malaysia
}

\begin{abstract}
A global pandemic caused by COVID-19 virus since December 2019 has developed into a fearsome situation more than any common global contagion. In combating COVID-19 worldwide, governments instigated a precautionary cordon sanitaire in various degrees. Live music, cinema and film festivals were inevitably cancelled, causing artists to become alienated from their audience. This paper aims to illuminate how practitioners of the creative industry cope with the drastic disruption due to the COVID-19 outbreak as well as the means of regenerating 'life', which refers to that of a creative artist in a narrower sense, and to that of the industry in a broader sense. Adopting a combined methodology of autoethnography and virtual ethnography, the authors explore their encounters with the informants and the development of the creative arts scene. The subject of disruption and regeneration in the creative arts industry is approached through feasible methods and tools they could render in this unique lived experience. They hope to construct a view containing some perspectives on the transcendence of creative practitioners from the disruption to the survival of the pandemic's impact, as well as the regeneration of how creative arts would persevere in the 'new normal' of the post-COVID-19 era.
\end{abstract}

Keywords: COVID-19, Cordon Sanitaire, Creative Arts, Disruption, Regeneration.

Received: 31 July 2020

Accepted: 19 April 2021

https://doi.org/10.33736/ijbs.3759.2021

\section{INTRODUCTION}

As of May 18, 2021, there has been an accumulative infected global population of over 163.6 million with a terrifying mortality of nearly 3.4 million (Johns Hopkins University \& Medicine, n.d.). While billions of people mourn for the loss of family, relatives and friends and mentally suffer when coping with the outbreak, the reality has subsequently showed that this pandemic has not just posed a mortal threat to public well-being but also an indicator of imminent devastation to

\footnotetext{
* Corresponding author: Faculty of Applied and Creative Arts, Universiti Malaysia Sarawak, Sarawak, Malaysia; Tel: (+60)-82 581390; E-mail: 1knconnie@unimas.my
} 
economy, politics, and social lives. For months in an effort of containing COVID-19 worldwide, governments instigated a precautionary cordon sanitaire of various degrees at district, municipal, provincial and even national levels. In Malaysia the Movement Control Order ${ }^{\mathrm{i}}$ [MCO hereafter] took effect on March 18, 2020 (Figure 1) in order to contain the contagion and to flatten the curve of virus infection. Many businesses ceased operations at the extreme measures of the lockdown restrictions while the authors witnessed a devastating reality of the enforcement of closed schools, deserted streets, blocked highways and cut airline routes. The economy was at its worst, especially with the retrenchment exercise practiced by corporations when many contract workers and freelancers were literally out of jobs. By March 2020, there was more than one third of the world population living under a form of lockdown restriction, and there were more than 25 million jobs at risk (Guest, 2020).

Figure 1: The Singapore-Malaysia Causeway on the eve of MCO when hundreds of thousands of Malaysians working in Singapore fled from Johor Bahru before the national border was closed for a seemingly infinite period, while the causeway was seen vacant on the first day of MCO.

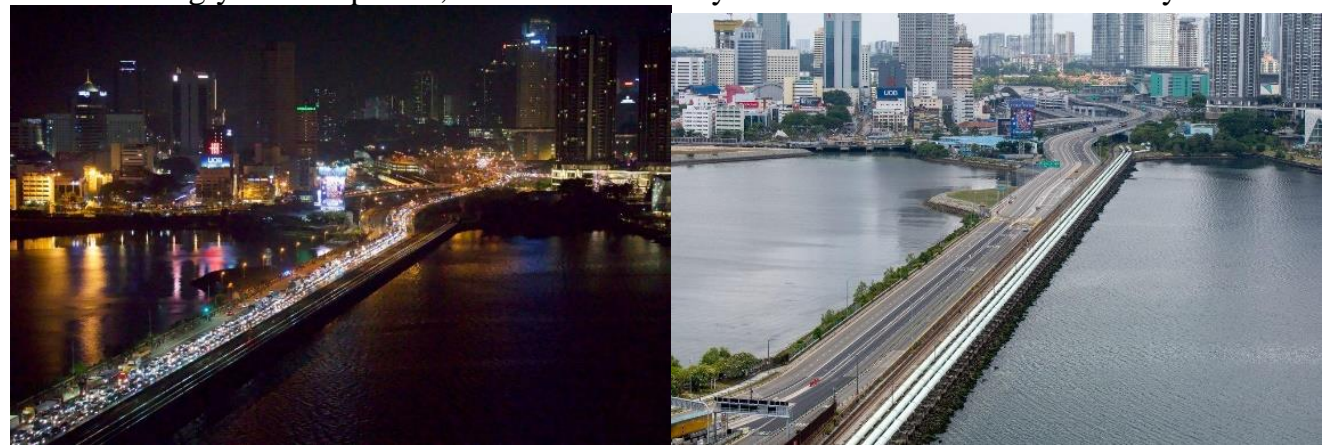

Source: Osman (2020).

The closure in regions and the imposed isolation that reduce physical contact among people have made an impact on businesses in the longer term, and some analysts believe that, unlike the global financial crisis in 2007-2008, it is not likely to return to a normal state (Guest, 2020). Along with the new vocabulary that has been quickly grasped in news updates, many fickle meanings have been suggested for an ambiguous future state called the 'new normal'. ${ }^{\text {ii }}$ Being obliged to not engage with social activities at public places, civilians are forced to be isolated in a form of quarantine and overwhelmed with strict measures to the extent of prohibited social gatherings, restricted traveling, and the cancellation of festive celebrations. Apart from the business and tourism sectors, the COVID-19 disruption has essentially affected the creative industry.

In compliance with the restriction on social gatherings, live music, dance, cinema, theatrical shows and on-site film festivals were either postponed or cancelled with no compromise at first, and slowly resumed from the tightest measure. Programmed concerts, gigs and shows were cancelled or rescheduled with a clear and present uncertainty that the dates were still susceptible to revision in the future. As the COVID-19 cordon sanitaire has shaken the foundation of globalisation (Guest, 2020), the global scene of creative art with collaborations of artists and filmmakers of different nationalities-from gigs to festivals-have been deeply impacted. 
Globally, in the vulnerable time of COVID-19, workers in the creative industry were those some of the most affected who faced the precarity immediately, especially in securing their basic needs for daily survival. Due to the indefinite lock down policy declared by most countries, film productions were stopped and cinemas, concert halls and performance spaces were closed due to safety measures in efforts to reduce a wider spread of the coronavirus. Since the worldwide lockdowns started, music performances, live concerts, film production, music and film festivals seemed to halt entirely, but were there transformations for the music and film industry? Seeing COVID-19 pandemic as a global crisis, it has significantly brought on a seemingly irreversible fracture in the means of accessing music and film, thus the people in the creative industries were forced to reinvent and recreate themselves in a virtual space. Observations have shown that people working in the industry, who are comprised of art directors, musicians, performers, film producers, film production crew, film festivals' directors and programmers partaking in the creative processes, were actively involved in open discussions about reinvention during the pandemic period.

Creative arts are defined as "an industry that is based on work in which original ideas are important, such as work in the arts or the media, in designing computer software, etc" (Cambridge English Dictionary, n.d.). In Malaysia, ten sub-sectors of the creative arts identified by the Malaysia Creative Industry Policies are performing arts; music; film, television, gaming content; visual arts; literature; fashion and design; traditional and cultural arts; creative technologies; creative education; and culinary arts (Ishak, n.d.). Under the Malaysian creative economy, each sector has its own traits and characteristics, skills and talents. In this paper, the examples used in the discussion focus on the impact brought by a disruption due to the COVID-19 outbreak towards music and film sectors in the local and global sense.

\subsection{Impact of COVID-19 towards Global Creative Economy}

The COVID-19 pandemic has plunged the world economy into a global recession. The pandemic also affected the whole ecosystem and the global chain of creative industries from the creative and production process to distribution and audience or viewer access. In this regard, creative workers play a vital importance in contributing to economic growth. Based on the forecast by United Nations Educational, Scientific and Cultural Organisation (UNESCO) in 2017, the creative economy contributes around $10 \%$ of global gross domestic product which comprises cultural and creative industry sectors generating an annual revenue of approximately US $\$ 2,250$ billion and over US $\$ 250$ billion from global export (UNESCO, 2017). Due to the global shutdown of live concerts, public performances and festivals, "one estimate shows that up to 25 million jobs will be eradicated, wiping out US\$860 billion to US $\$ 3.4$ trillion in labour income" (UNESCO, 2020). The unprecedented outbreak of the COVID-19 pandemic has affected creative workers and rendered them unemployed. In the film industry per se, more than 170 thousand crew in the U.S. and U.K. were reported to have lost their jobs (Giardina, 2020; Pulver, 2020) while a staggering number of nearly 650 thousand Bollywood crew were affected due to the pandemic (Dasgupta, 2020).

Unemployment of production crews during COVID-19 led to loss of income and an increase in anxiety rendered by the uncertainty of the extent of the lockdown, as to when they would be able to resume jobs without which they will not be able to pay their bills (Bectu, 2020). In a survey conducted by the Broadcasting, Entertainment, Communications and Theatre Union, a U.K. union which represents 40,000 individuals across the media and entertainment industry "identified that 
over half of freelancers surveyed had lost money as a direct result of the pandemic" (Wilson, 2020). Out of 5,600 freelancers who took part in the survey, $46 \%$ have reported lost money since the outbreak. From 1,500 respondents who provided details of their loss, about two-thirds revealed a loss of at least $£ 2,000$ which was just before their government's recommendation of widespread social distancing. In the same report, the amount of losses due to COVID-19 was expected to be over $£ 40,000$ while the length of lockdown was yet to be known, at least not until the vaccine is available to the general public. In the UK, the music industry had contributed $£ 5.8$ billion to the UK economy in 2019 , in which a musician earned approximate income $£ 23,059$ individually prior to the COVID-19, and currently, musicians and songwriters have lost $65 \%$ of their total income due to the global recession (Savage, 2020). Since March 2020, musicians and performers who solely depended on studio recording and live performances, their income was razed to zero due to the disruption brought by the pandemic (Ramachandran, 2020).

On a global media industrial level, a forecast by the Ampere Analysis firm projected a staggering loss of $\$ 160$ billion over the growth in the next five years in which the theatrical sector set to experience the hardest hit in 2020 onward (Szalai, 2020). While online streaming services are the sole "big winners", the theatrical sector is projected to "lose $\$ 24.4$ billion over the next five years" (Katz, 2020). This has inevitably disrupted the way films were conventionally distributed and exhibited, which prioritises theatrical releases before they are sold in other platforms such as TV and online streaming. This also means that many film productions which are still opting for the conventional release window might be slowed downed in years to come (Katz, 2020).

In Malaysia, approximately 10,000 Malaysians nationwide are part of the creative economy machinery whose livelihood had been inevitably impacted by COVID-19 (Sallehudin, 2020a). As part of the creative industry, there are approximately $80 \%$ of production crew members in Malaysia who are paid on a daily basis (Abdullah, 2020). In other words, when film productions were suspended due to MCO, filmmakers who freelance by nature were inevitably out of job. Another survey conducted by Malaysia's Culture Economy Development Agency (CENDANA) found out that an average of $93 \%$ of the respondents were negatively impacted by the COVID-19 pandemic as $76 \%$ of their activities were arts events, including public or private exhibitions and arts education-related events that were either cancelled or postponed ${ }^{\mathrm{iii}}$ (CENDANA, 2020a). In the same report, it was also found that at least $70 \%$ suffered from financial losses in pursuant to lockdown and their inability to generate their incomes as per before the pandemic crisis.

Meanwhile, at the individual level, $44 \%$ of the respondents reported a loss of approximately RM1,000 to RM5,000 or more per week during the outbreak (CENDANA, 2020a). While on a larger scale of the industry, performance spaces were forced to close the premises in order to prevent the spread of the pandemic. The Kuala Lumpur Performing Arts Centre (KLPac), a prominent example, estimated a loss of more than RM630,000 from mid-March to October 2020 as there was no revenue from ticket sales from concerts and theatre productions, venue rental and academy courses (Maganathan \& Toh, 2020). Within the stretch of eight months, 41 scheduled shows were postponed or cancelled. This data clearly demonstrates the impact of the pandemic on the social fabric of the life of the creative workers as well as the economic impact on the creative industry.

With unprecedented cordon sanitaire restrictions and a renewed relevance of a geographicalpolitical economy through "capitalism's annihilation of time by space" as well as that "of space by 
time" (Ward, 2020, p.191), knowledge and response to the coronavirus have impacted the local and global creative industry. The world devastated by COVID-19 was shaped, presented and linked via modern-day technology as a chunk of intertwining phenomena. This brought in the indispensable components of the lived experience specific to a community, enabling researchers to simultaneously inspect the many realities as narrated by individuals who are affected by the world they live in (Lopez \& Willis, 2004, pp. 727-729). This paper is a result of observation conducted from March to October 2020 on the development of the COVID-19 outbreak and its consequences on society and the creative industry. The exploration is both descriptive and interpretive with a focus on examples of creative works from Malaysian music and film sectors as well as an extended discussion of striking ideas for music performances in the post-COVID-19 era as seen from abroad. It is hence an effort to present in the following segments some perspectives on the responses from the creative arts in the light of the COVID-19 pandemic. It is the outcome of an eight-month observation of the disruption that occurred when cities and nations worldwide halted economic operations for cordon sanitaire, including Malaysia for its first 3-month Movement Control Order, as well as signs of regeneration which were observed one month since then. The authors hope to offer an initial insight on the disruptive changes and how practitioners of the creative arts transcended from this unsettling setback to a regenerating phase via mundane, remote communicative applications.

\section{LITERATURE REVIEW AND METHODOLOGY}

The outbreak of the COVID-19 pandemic caused negative impacts which brought both internal and external disruption to the creative arts industry locally and globally. Most of the arts practitioners in the creative industry have precarious jobs, having a freelance tenure where they are agile in adapting consequential changes in different production and working conditions (Morgan \& Nelligan, 2018; Curtin \& Sanson, 2016; de Peuter, 2011). Musical theatres, galleries, concert halls, and performance spaces were shut down with the enforced, temporary cordon sanitaire for which no end date was fixed in the height of outbreak. Art exhibitions, music festivals, indoor and outdoor events were postponed to an unknown date, while music, film and theatre productions were suspended indefinitely. The status quo of the unfixities posed an enormous threat for artistic directors, festival programmers and curators to plan for future events, as the new 'normal' may seemingly extend to the following years. The creative workers started to redefine themselves, reinvent and recreate their performances as well as productions in order to sustain their creative life in order to earn a living during the pandemic era.

The COVID-19-induced recession in 2020 has been widely compared with the Great Depression of the 1930s as the historical reference point (Ward, 2020, p. 191; Wheelock, 2020). In the face of the COVID-19 stroke, two key concepts are applied in this paper: 'disruption' and 'regeneration'. Inspired by the research work of Buckley and Ward (2015), the idea of a 'disruptive change' immediately emerges in the sense-making of human lived experiences that could be visited in the post-COVID-19 era. Firstly derived within the business management community, 'disruptive change' refers to "a sudden shock that quickly and irreversibly changes a company's expected future, challenging existing business models, values and norms" (Christensen \& Overdorf, 2000), as 'shocks' for these events include "economic crisis, 9/11, or an innovative competitor that disrupts the market-share balance" (Buckley \& Ward, 2015, p.11). Apart from the business community perspective, this paper employs the idea of 'disruptive change' applied by Buckley and 
Ward (2015) to a wider scope on the "changing geopolitical, technological, socioeconomic and environmental trends"-including natural disasters, emerging technologies, climate change and poverty — and their motivators over a period of a decade or two (2015, p. 5, p. 12).

In the research by Buckley and Ward (2015) with non-governmental organisation (NGO) leaders and highly experienced development practitioners in the global South facing uncertain and turbulent operating environments challenged by both external and internal disruption, they detailed how their respondents in the global South "have adopted for anticipating, engaging with, and responding to disruption" both external and internally $(2015, \mathrm{p} .5)$. Although creative workers were not singled out in the concept of 'disruption' by Buckley and Ward (2015), their attention to how disruption shaped institutional leaders and development practitioners certainly draws a parallel to the focus of this paper, namely to the creative workers or practitioners whose income is generated mainly from their involvement in the arts and creative industry. In the same light, this paper examines how creative workers were disrupted by the pandemic, an ostensibly external disruption that brings along internal disruption to creative workers both globally and locally.

Meanwhile, the term 'regeneration' generally carries two meanings: (1) "to improve a place or system, especially by making it more active or successful"; (2) "to grow again" (Cambridge Advanced Learner's Dictionary \& Thesaurus, 2020). In the social sciences, researchers commonly associate this term with the development of culture (Wu, 2004; Cerreta, Daldanise, \& Sposito, 2018) and community art (Remesar, 1999; Kay, 2000; Cameron \& Coaffee, 2005). Therefore, this term is used in this study as a sign of revitalising change after the disruption as observed in art practitioners as well as the trend of performing arts.

Exploring how the COVID-19 pandemic had an impact on the music and film industry, the authors as academics from three different disciplines in creative arts were engaged. Observations and analysis during the MCO period in Malaysia with the shutdown of university campuses, various partially locked-down cities and towns, the closure of international border and a suspension of domestic and international flights were witnessed. Combining both autoethnography and virtual ethnography methods, the precarity of the creative workers was examined through their "intersections, negotiations, collisions, and coalesces" during isolation periods at the same time reinventing themselves through collaborative performances during the COVID-19 pandemic (Spry, 2016, p.26). Anchoring the themes of this research focuses on the impact of both internal and external disruption towards precarious creative work, creative collaboration and streaming, the strategic "auto" methods are where the authors were positioned as academics who observed the unusual phenomena of music and film industry through the remote interaction with the people within the creative industry. Taking further on the vantage point, one of the authors is a festival programmer who reflects on his experience migrating the film festival from physical to online in response to the prevention of COVID-19.

The authors are in search of the state of precarity of these creative workers before the outbreak of the COVID-19 pandemic and their transformation during the crisis by reinventing themselves for streaming purposes. Highlighting the transformation process, this study was briefly conducted through an autoethnography method that underlines the authors' first-person experiences of both the phenomenon as an object of interest from the COVID-19 pandemic to the process, the music and film practice and collaborative music making, and the creation and the process of knowledge discovery (Pensoneau-Conway \& Toyosaki, 2011). Adapting the automethodological components 
proposed by Bunde-Birouste, Byrne, and Kemp (2019) by combining three components: auto refers to the researcher undertaking self-observation based on his/her own experience, ethno referring to the epistemological framework, where the disruption of music and film industry were explored as a phenomenon during the COVID-19 pandemic and graphy referring to the research process.

This qualitative study adopts mixed methods of autoethnography and virtual ethnography in order to examine the disruption and regeneration processes triggered by the COVID-19 outbreak in 2020. An ethnography is a scientific study of culture with a concern of "descriptive documentation of the sociocultural relationships within a given research environment" (Bunde-Birouste et al., 2019, p.509). However, like other civilians in the country, the authors abided by the MCO enforcement and were limited to the mandated stay-at-home policy and socially distancing from face-to-face interactions, thus restricted from physical contact with respondents and informants to a certain extent.

In this unique circumstance, autoethnography and virtual ethnography in combination emerged as the most appropriate and strategic method to approach the data of the subject. Autoethnography is described as "a way to conduct traditional ethnography with a significantly enhanced role for the researcher" who "is visible, a "strong member" in the study of the culture itself (Vryan, 2006, p. 47; Bunde-Birouste et al., 2019, p. 513). Conducted differently from conventional ethnography, ethnographers also took part in the construction of meaning and values in the studied culture, while the reflexive nature of the research involved "self-observation within a social or cultural world to which they necessarily belong" (Pensoneau-Conway \& Toyosaki, 2011; Bunde-Birouste et al., 2019 , p. 513). Virtual ethnography, or alternatively known as "ethnography for the $\mathrm{E}^{3}$ internet", is understood to be the most effective approach to embark an ethnography without establishing an actual physical connection with a field site and the informants. Coining $\mathrm{E}^{3}$ as "the embedded, embodied, everyday internet" (Hine, 2015, pp. 19-54), Hine has even dispensed with the epithet 'virtual' in order not to mislead the way this method is understood. Hine elaborates some key components of this type of ethnography, where the attributes of 'field' and 'internet' and the role and responsibility of 'ethnographer' are adaptively defined and constructed (Hine, 2015, p. 88).

Despite the enforced cordon sanitaire, voice telecommunication, the applications of social media, conference room software and content streaming media platforms were employed as research tools which were conveniently available and manageable for the purpose of this study. This investigation acquires the research data via three sources:

(1) Lived experience: Information, narratives and essential data or highlights as observed from the authors' lived experience in both offline and online modes;

(2) Remote, personal interviews: Two selected informants according to their credentials as practitioners in the creative arts industry in Malaysia as well as an established connectivity with the researcher;

(3) Examples of digitally streamed production: Selected videos that demonstrate inspiring ideas in audio visual productions during various stages of cordon sanitaire in Malaysia. 
Figure 2: A summary of the methodology of this study

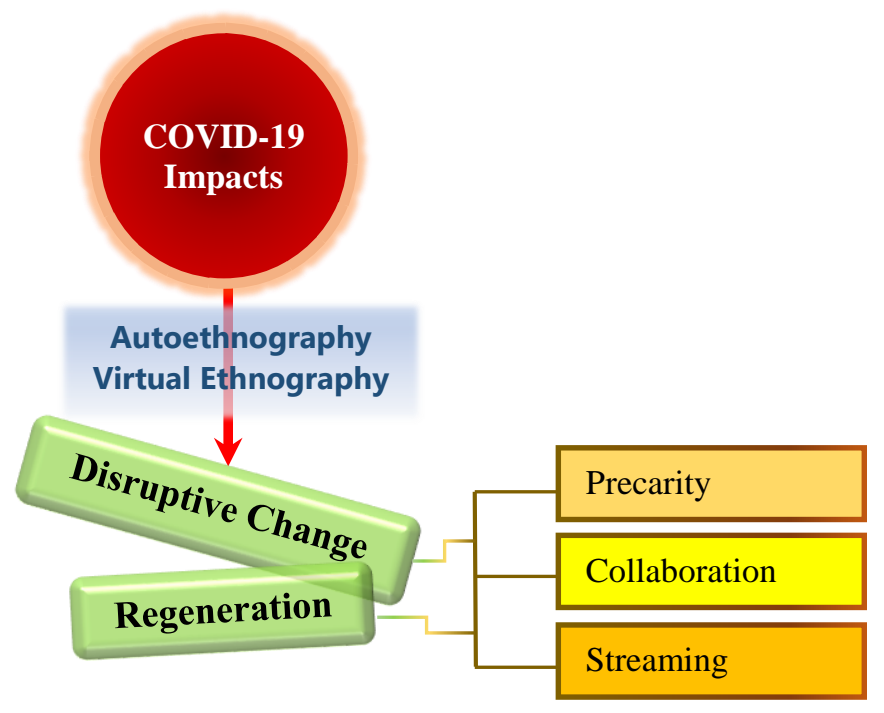

Through data gathering and analysis, the authors derived three corresponding themes which are significantly essential for the discussion of the disruptive change and the regeneration for creative workers: diminishing the precarity of creative workers, engaging in creative collaboration and shifting to streaming platforms. The outcome of the study hence induced to illustrate, within the limited scope of the study, how local and global creative artists coped with the disruptive change initiated by the COVID-19 pandemic and engaged with a regeneration in their artistic works.

\section{RESULTS AND DISCUSSION: FROM DISRUPTION TO REGENERATION}

The spread of the COVID-19 pandemic brought a disruption of life to the arts practitioner. When being quarantined, people were restricted to live in an individual's confined space and experienced an alienation of time and space. The current disruption has changed the ecosystem in the creative arts industry. It changed the lifestyle of society especially on how music and film were consumed. This generated an immediate problem brought on by COVID-19 to arts practitioners who had to secure the basic needs for their survival. In our observation during the early lockdown period, all performance and screening venues accessible to the public were closed, causing a suspension of the operation of music and filming productions. Nothing seemed promising in terms of the availability of physical platforms for musical performance, and no film production was allowed to take place until the standard of procedures in production was endorsed by the authorities. This rendered precarity to creative workers whose working condition was already deficient before COVID-19. Notwithstanding the challenges brought on by COVID-19, the authors, however, have observed how musicians, artists, filmmakers and festival organisers have transformed themselves in order to survive the difficulties never before encountered. Hence, three themes become apparent in this paper: 

i. $\quad$ Diminishing the precarity of creative workers
ii. Creative collaboration during isolation
iii. $\quad$ Reinventing the usage of live streaming through technology

\subsection{Diminishing the Precarity of Creative Workers}

The nature of jobs in the creative industry is extremely precarious. Many in the industry work independently as freelance artists, musicians/performers, music producers, concert or festival crew, film producers and production crew. This means creative workers are paid on a project basis for their engagement without the insurance of a safety net such as Employees Provident Fund (EPF) and retirement funds needed during their older age. Apart from that, they often encounter irregular workloads, not getting paid on time and in some cases their wages are absconded altogether due to the fact that freelancing is not recognised formally as a career by governments, hence they are not protected under employment laws (HR Asia, 2017). These scenarios were common before the COVID-19 disruption, and their precariousness worsened since they became technically unemployed due to the infinite postponement or cancellation of their arts projects. For instance, given the fact that most of the creative industry workers in the advertising film industry are dailypaid freelancers, COVID-19 had rendered them impoverished and "literally starving" (Zahiid, 2020; Khoo, 2020).

Due to this unprecedented disruption brought by the pandemic, it had caused an opportunity loss at worst, or a reduction of opportunity at best. All these losses will not be recoverable within a short period of time. There are musicians who have lost their freelancing jobs due to cancellation of concert tours and are shifting to other industries to earn a living. As a performing musician who

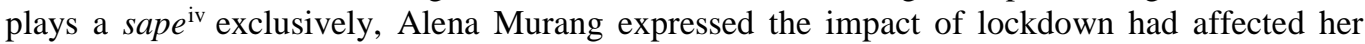
income. All her scheduled shootings, recording sessions and live shows in music festivals were cancelled (Alena Murang, personal communication, July 21, 2020).

In fact, musicians are not all alone in facing the predicament brought by the COVID-19 pandemic. Filmmakers and production crews are experiencing similar precarity in their own plight. For instance, in one of the letters to the editor published on "The Star", Khoo Kay Lye, the president of Malaysian Association of Advertising filmmakers, wrote that "when TV and video commercials are produced, hundreds and even thousands of crew members with different skill sets get to work; with the enforcement of the MCO, almost all film production jobs have been halted... the result is simple-no job, no food" (Khoo, 2020). Similar sentiment was also shared by the panellists of "No One Left Behind?" organised by the "Facebook page Malaysia Freelance Production Crew-TV /Film/Video". Chua (2020) has reported that Jurey Latiff Rosli, one of the panellists of the webinar who is also the president of Malaysian Television Producers Association (PTVM), expressed his concerned over the plight of his fellow industry workers: "Our industry has been affected badly by the Movement Control Order (MCO), and many of us have suffered loss of income as a result of the halting of filming".

In addition to both artists and filmmakers, film festival organisers, cinema theatre operators and their staff has experienced similar precarious conditions as well. Playing a role as the medium that connects both film productions to their audiences, many film festivals and cinema theatres operations were put on temporary halt as part of their obligation in complying with SOPs (standard 
operating procedures) and demand to avoid the spread of COVID-19. Since March 2020, many international film festivals and blockbuster film screenings were postponed to a later date, and some even opted for screenings in the following year (IndieWire Staff, 2020). In Malaysia, instances were the 31st Malaysia Film Festival, the 4th Malaysia International Film Festival (MIFFest), and the 19th French Film Festival organised by Alliance Française and the Embassy of France in Malaysia, which would involve large gathering of physical audience, filmmakers and organising teams, that they were either postponed to a later date with some adjustments of their initially planned events or cancelled altogether (Omar, 2020; Chow, 2020; Malaysian National News Agency, 2020). In a similar vein, many cinema theatre operators were reported suffered revenue loss (Hassandarvish, 2020) and one of the operators has had their contract workers furloughed temporarily "in view of the long closure, as a measure to manage (their) manpower effectively” (Choong, 2020).

Figure 3: Poster announcing the postponement of "Call for Submission" posted on Mini Film Festival's social media.

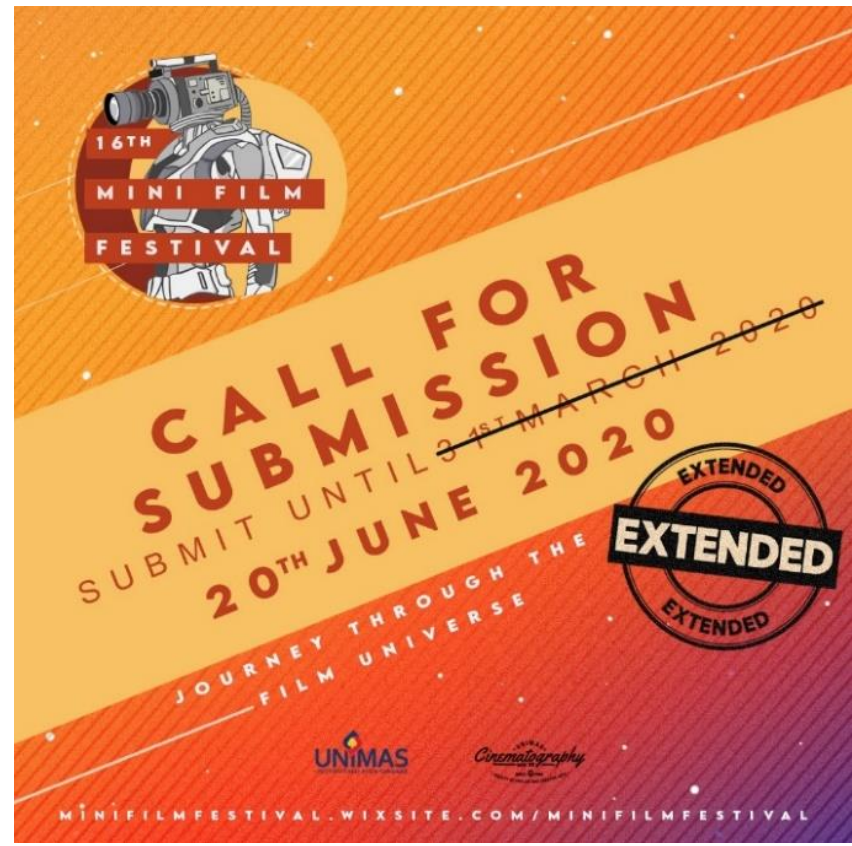

Source: Mini Film Festival (2020b).

On another hand, the organiser of the 16th Mini Film Festival, the longest running short film festival in Malaysia was perplexed by the uncertainty brought by the pandemic. There was no exact date of when the lockdown would be lifted as several extensions of the lockdown had been announced in contingency to the seriousness of the pandemic in Malaysia. In such circumstances, all the planned activities and preparation for the festival were put on hold for a seemingly infinite duration depending on when the lockdown would be lifted. One of the obvious challenges to the festival organiser was that the initial film submission deadline as well as the festival dates were 
unprecedentedly postponed, causing an anxiety for the organiser due to the uncertainty of when they could organise the festival physically as per planned earlier (The Star, 2020; Desk, 2020).

\subsection{Creative Collaboration during Isolation}

Since the lockdowns, there has been no opportunity for live performances. Immediately, musicians, performers and artists started to turn to live streaming as a new performance space. Coping with a performance space, whether it is a concert hall, cathedral, open spaces or private home, the absence of physical audience from the venue has meant a great challenge for musicians in communicating musical ideas as well as capturing audiences' response through their applause and emotional resonance. Andrew Bong, a Malaysian film music composer who currently resides in Los Angeles, has to rely on the internet, social media and various streaming platforms since the lockdown started. Although working in isolation on his digital audio workstation (DAW), he was still able to work together with composers, music arrangers, performers and soloist, doing new music pitches and production meeting (A. Bong, Personal Communication, July 27, 2020).

It was a new social experience when musicians, composers, songwriters from different parts were connected through internet and online collaboration tools. A platform of internationalisation for global dialogues in music was created, and a collaboration in music making through local and international connections during the lockdown periods has been made possible. A global crisis could hence be transformed into opportunities for the arts practitioner during cordon sanitaire, connecting remotely composers, songwriters and musicians from different parts of the world. While being isolated at individual homes, musicians, artists and performers were still manage to create own opportunities through community building.

Figure 4: Nadiah Hamzah, a film director, interacts with her crew during the production of the first Malaysian commercial shot remotely during COVID-19 lockdown.

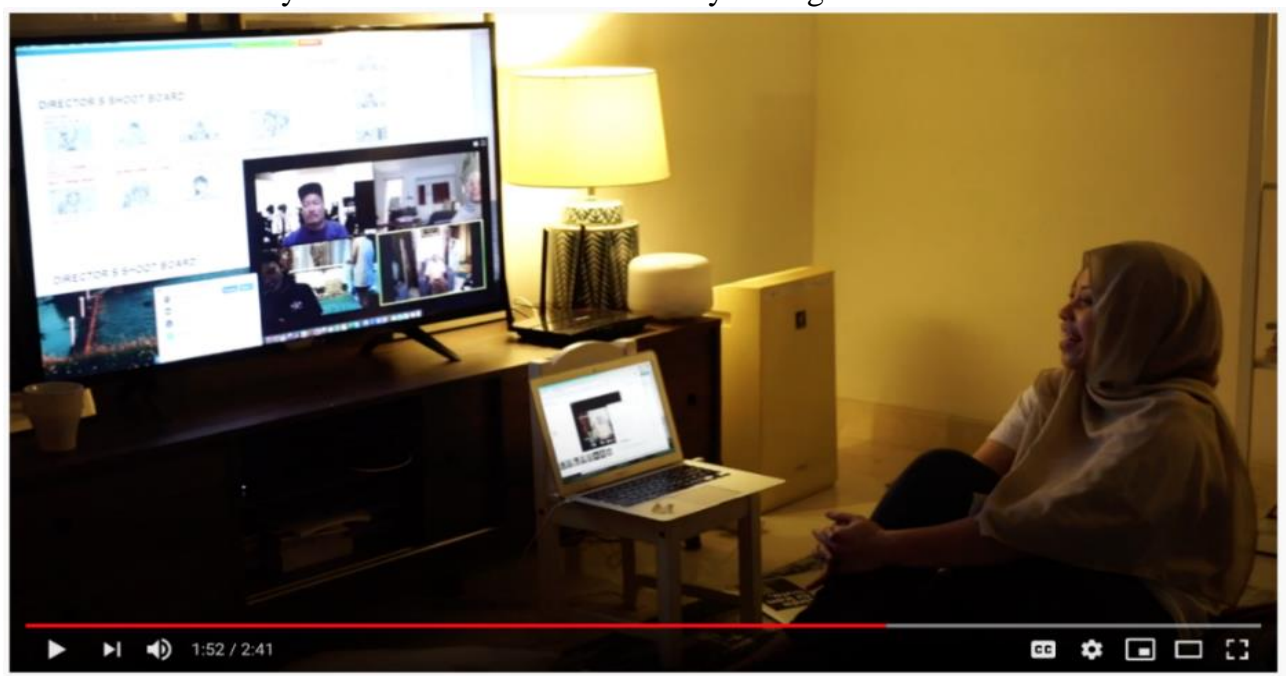

\#RayaStyleLain miklanRaya "StayHome

Iklan Raya vivo 2020 - Behind The Scenes 
Source: Wayang Works (2020).

Although the film industry in general has been curtailed by the global pandemic crisis, not all filmmakers and productions have given up entirely. In fact, they reinvented themselves in order to produce commercial films and advertisements in an experimental experience. Among others, Nadiah Hamzah, a filmmaker, has directed a commercial advertisement for a smart phone brand with her crew in an entirely remote fashion despite the cordon sanitaire (Figure 4). In an effort to offer an online discussion related to the challenges brought by the COVID-19 pandemic as well as the creative solutions innovated by local film productions in response to the crisis, Yow, the moderator, has invited Nadiah Hamzah to share her first-hand experience in directing the advertisement. In the webinar, she elaborated the way she taught each actor how to set up their cameras (Mini Film Festival, 2020a).

Figure 5: A snapshot from the teaser of "SMK Raya Dekat Jauh" directed by Shamyl Othman with 9 young actors shot using their mobile device. The production is regarded as the first telemovie produced during cordon sanitaire in Malaysia.

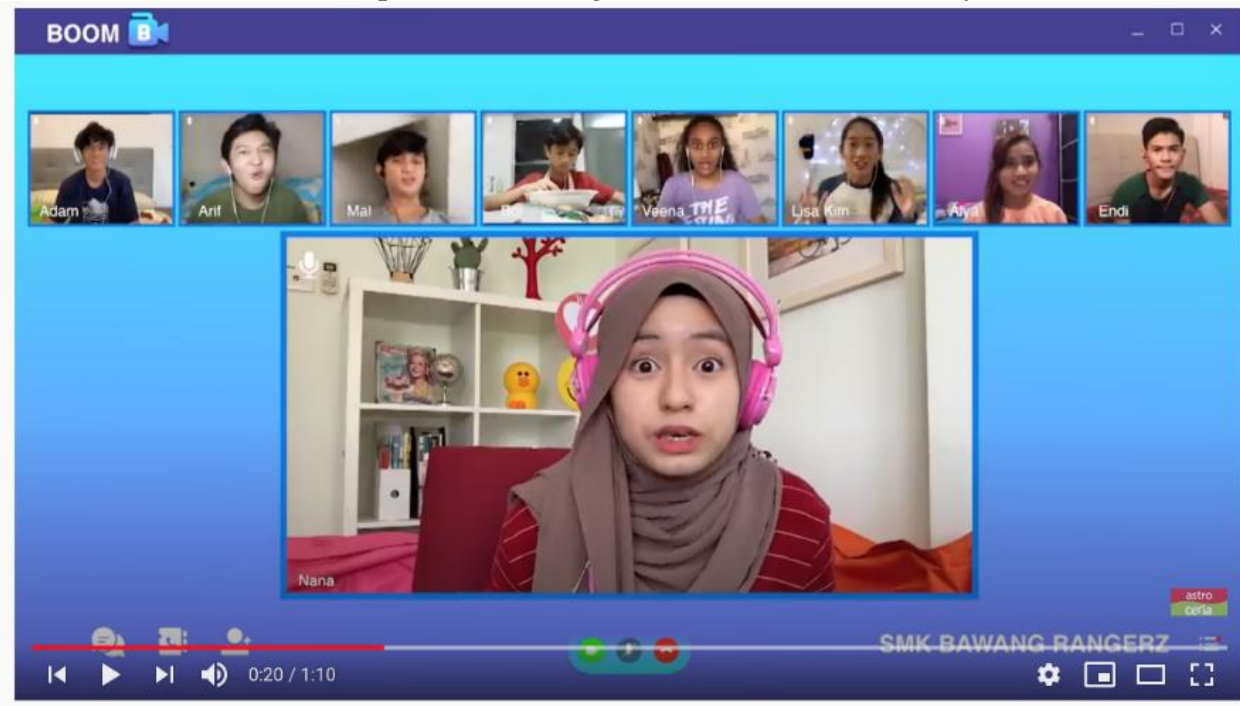

\#SMKkita \#SMKRayaDekatJauh \#AstroCeria

Telemovie PKPB Pertama di Malaysia | SMK Raya Dekat Jauh | 7 Malam Ini | Teaser

193,865 views * Jun 5,2020

If $2.1 \mathrm{~K}$ \& $121 \Rightarrow$ SHARE $\equiv+$ SAVE $\ldots$

Astro Ceria 0

966K subscribers

Source: Astro Ceria (2020).

A longer time spent during production and production roles rendered to actors without film production background were the two most cited challenges in the webinar discussion. Both challenges are closely interlinked and often instigated by the latter, given that without crew on location, actors who are not equipped with production skills will encounter greater challenges in 
picking up production roles which in common practice are segregated according to departments, such as camera, sound and production design. In such settings, an innovation for production during MCO without production crews on location was to adopt different storytelling method. This was driven from the point of view of a web camera or a mobile phone as to compensate the visual for " not having to look so great", and thus "things are supposed to look a bit more raw" (Mini Film Festival, 2020a). Shamyl Othman, a filmmaker who directed a telemovie entitled "SMK Raya Dekat Jauh" (Figure 5) during the MCO, added, "we could go down that route and that sort of (approach) helped a lot. I mean, there is no way we could finish in five days (in conventional setting during pre-pandemic time). So, we did a 45 minute [telemovie, that] is sort of special in five days with nine talents" (Mini Film Festival, 2020a).

In the same light, filmmakers seemingly adopted a similar approach in producing their digital contents during the lockdown, including a short film entitled "Geng Kelambu" (Figure 6) in which Shamyl Othman played a character. The story revolves production crew and actors portraying a group of friends who spend time on a video conferencing platform "reminisce about the spirit of the friendship they once shared and their promise to always look out for each other" (Chooie, 2020). Being a result of collective collaboration between production crew and actors and shot in isolation without production crew present on location, this short film was produced during the MCO "despite the lack of money and challenges" that the filmmakers and actors were facing (Chooie, 2020). The short film was premiered by Chooie Zena, the executive producer, on Malaysia Freelance Production Crew's Facebook page.

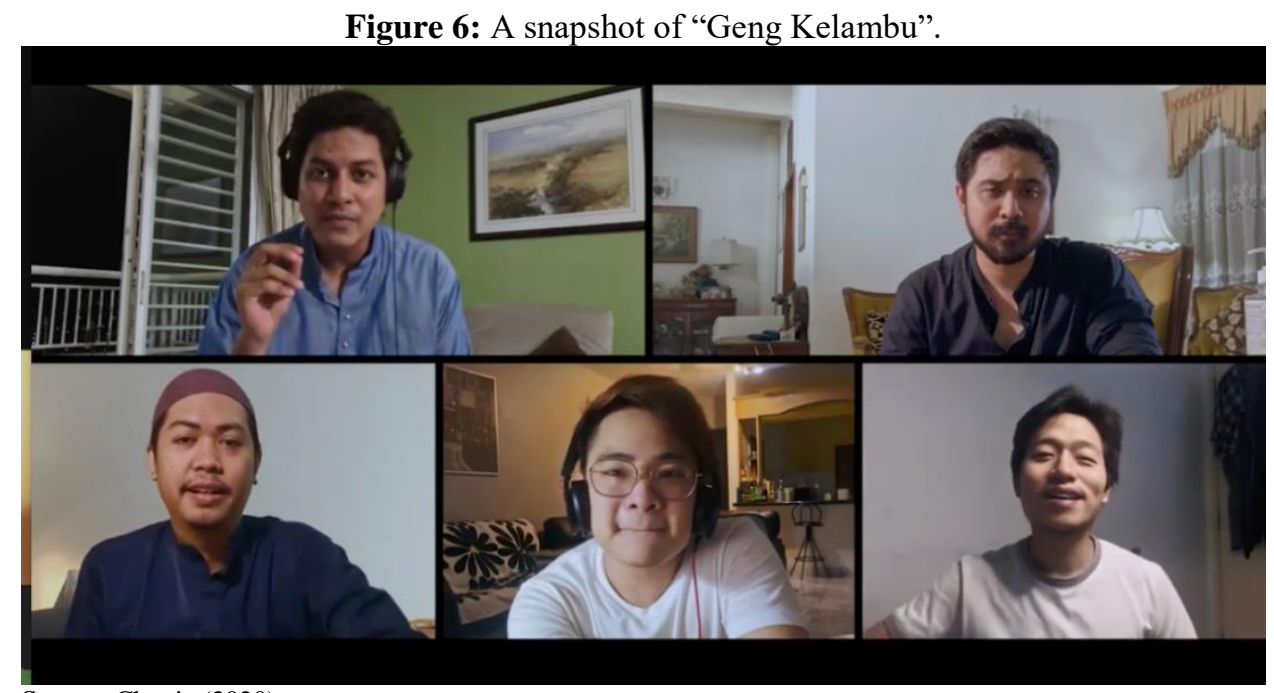

Source: Chooie (2020).

\subsection{Reinventing the Usage of Streaming Platform through Technology}

Online streaming is a mediated technology that enables media content being accessed through internet data streaming on designated platforms, such as YouTube, Facebook, Twitter, Tik Tok and Bilibili. With a device equipped with broadband network technology, users no longer need to 
purchase physical media artefacts or to download the media files for playback but can access the available content anytime and anywhere through an 'on-demand' streaming transmission. Apart from the access of pre-recorded content, which is the most common type for online streaming, livestreaming services emerge as a popular option in media broadcast predominantly on YouTube and Facebook which synchronise an event with remote viewers practically at real-time. This trending option resembles a live television broadcast, but it allows interactivity between content providers and their audience whereby the elimination of the authoritative control of a broadcast corporation or institution is technically made possible. Due to a wider coverage that surpasses any conventional media broadcast, spatial boundaries in streamed media have become more indefinite and undefined. Local and global contents are made available on the same platforms, and broadcasters from various sites learn from each other.

The COVID-19 outbreak led to a long-term suspension of live performances and filming processes, but it has induced enormous creative productions of streamed media since March 2020. Live performances were transformed into live-streamed events where performers staged a real-time live performance without an on-site audience but engaged the entire performance with filming for the internet broadcast. There were also COVID-19-themed artistic events curated with real-time performances made accessible for a global audience. Instances are Malaysia's "Muzik Dari Rumah" starting from April 8, Rene Liu's 劉若英 “For You” Online Concert on April 17, World Health Organisation's "One World: Together at Home" Global Special on April 18, China's "Believe in the Future” Online Charity Concert 相信未来 on May 4, May Day's 五月天 “Live in the Sky” on May 31, and Alena Murang's "Spirit" on June 3.

Locally, the music industry was not entirely silenced by the lockdown brought by COVID-19 pandemic. In fact, many musicians had reinvented themselves by creatively collaborating with other musicians in seeking opportunities to reconnect with their potential audience virtually. Musicians like Alena Murang set up home studios and collaborate with other musicians virtually. As seen in other parts of the world, musicians were forced to reinvent themselves and collaborate with other musicians and production crews in streaming their performances and gigs on digital platforms (Karmy \& Urqueta, 2020) at the same time, using social media as the means of publicity. Creative workers reinvented themselves to become content creators in order to monetise through internet platforms such as YouTube, Instagram and Facebook.

Meanwhile, in the film industry, over-the-top streaming service providers demonstrated a spike of subscriptions during the lockdown period. An expected whopping 55\% annual growth rate from $\$ 104.11$ billion in 2019 to $\$ 161.37$ billion in 2020 was reported (Business Research Company, 2020). Netflix, one of the world's leading streaming companies, has recorded a spike of almost 16 million subscriptions worldwide from the previous quarter to total nearly 183 million (AFP, 2020). According to the British Broadcasting Corporation (2020), a new harvest of " 7.5 million members in the three months to the end of June" was to be expected by Netflix. These figures resonate in Malaysian creative arts industry, as per reported by CENDANA in a survey conducted with 692 participants from selected arts and culture or live events organisations across Malaysia. A staggering " $92 \%$ of Malaysian audience who normally would participate in arts activities or visit art exhibitions, performances and more would prefer not to leave their homes" (Sallehudin, 2020b). In the same report, $78 \%$ respondents agreed or strongly agreed that digital activities provide safety, while $22 \%$ expressed their likeliness to resume visiting the cinemas after six months, with the 
condition that COVID-19 cases were reduced tremendously to zero and vaccinisation is available in the near future (CENDANA, 2020b). Hence, online streaming of arts and cultural events as well as a migration of film screenings or film festivals to online platforms are the way forward for musicians, artists, filmmakers and film festival organisers.

\section{CONCLUSION}

By the time this paper was published, Malaysia was still under a reinstalment of cordon sanitaire with far greater rates of daily positive cases and a mortality rate ${ }^{v}$ than those in March-October 2020 , although vaccination has been introduced and signs of recovery were noticeable. While envisaging the post-pandemic period intertwined with the ever-changing socio-cultural, political and economic ramifications of society, it is still unknown how future researches could engage more discussion on the further development of the 'new normal' creative arts industry and imminent challenges post-COVID-19 that could be expected. Nevertheless, considering the current phenomenon as a crisis in the creative industry, it is worthwhile to document relevant observations during $\mathrm{MCO}$ as well as to raise essential inquiries to explore the currently precarious state of creative workers, to discover new values of creative collaboration and other trailblazing opportunities via internet platforms enhanced by digital streaming technology in the pandemic time.

\section{ACKNOWLEDGEMENT}

The authors would like to express their gratitude to Faculty of Applied and Creative Arts, Universiti Malaysia Sarawak for the research funding and support.

\section{REFERENCES}

Abdullah, S. (2020, August 3). Malaysia film industry to get moving in six months. The Star. https://www.thestar.com.my/lifestyle/entertainment/2020/08/03/malaysia

-film-industry-to-get-moving-in-six-months

AFP (2020, April 23). Netflix sees subscription surge during COVID-19 lockdown. New Strait Times. https://www.nst.com.my/world/world/2020/04/586786/netflix-sees-subscriptionsurge-during-COVID-19-lockdown

Astro Ceria. (2020, June 5). Telemovie PKPB pertama di Malaysia |SMK Raya Dekat Jauh| 7 malam ini | teaser [Video]. YouTube. https://youtu.be/49i7EFsqEUU

British Broadcasting Corporation. (2020, April 22). Netflix gets 16 million new sign-ups thanks to lockdown. https://www.bbc.com/news/business-52376022

Bectu (2020, March 18). Freelancers' top fear is how to pay the bills, finds Bectu coronavirus survey. Bectu. $\quad$ https://bectu.org.uk/news/freelancers-top-fear-is-how-to-pay-the-bills-findsbectu-coronavirus-survey/

Buckley, L., \& Ward, H. (2015). Getting good at disruption in an uncertain world: Insights from southern NGO leaders. IIED working paper. International Institute Environment and Development. 
Bunde-Birouste, A., Byrne, F., \& Kemp, L. (2019). Autoethnography. In P. Liamputtong (ed.), Handbook of research methods in health social sciences. Singapore: Springer.

Business Research Company. (2020, June 12). Surge in demand for over-the-top content (OTT) streaming channels due to COVID-19 - TBRC report insights. Cision PR Newswire. https://www.prnewswire.com/news-releases/surge-in-demand-for-over-the-top-contentott-streaming-channels-due-to-COVID-19---tbrc-report-insights-301075023.html

Cambridge Advanced Learner's Dictionary \& Thesaurus. (2020). Regenerate. Cambridge advanced learner's dictionary \& thesaurus. Cambridge University Press.

Cambridge English Dictionary. (n.d.). Creative industry. The Cambridge English Dictionary. $\begin{array}{llll}\text { Retrieved } \quad \text { December } & 31, & \text { from }\end{array}$ https://dictionary.cambridge.org/dictionary/english/creative-industry

Cameron, S., \& Coaffee, J. (2005). Art, gentrification and regeneration - from artist as pioneer to public arts. European Journal of Housing Policy, 5(1), 39-58.

Cerreta, M., Daldanise, G., \& Sposito, S. (2018). Culture-led regeneration for urban spaces: Monitoring complex values networks in action. Urbani Izziv, 29, 9-28.

Christensen, C. M., \& Overdorf, M. (2000). Meeting the challenge of disruptive change. Harvard Business Review, 78(2), 66-76. https://hbr.org/2000/03/meeting-the-challenge-ofdisruptive-change.

Chooie, Z. (2020, May 20). In Malaysia Freelance Production Crew - TV/Film/Video [Video]. Facebook. https://www.facebook.com/694630238/videos/10157995512030239

Choong, J. (2020, May 26). Cinema companies in Malaysia tighten belts amid revenue downturn from MCO. The Malay Mail. https://www.malaymail.com/news/malaysia/2020/05/26/cinema-companies-in-malaysiatighten-belts-amid-revenue-downturn-from-mco/1869746

Chow, V. (2020, June 30). Malaysia's MIFFest Planning Smaller Real-World Edition (Exclusive). Variety. https://variety.com/2020/film/asia/malaysia-miffest-festival-smaller-real-worldedition-1234694139/

Chua, D. (2020, May 15). \#Showbiz: Filmmakers seek urgent talks with PM on resuming industry. New Straits Times. https://www.nst.com.my/lifestyle/groove/2020/05/592880/showbizfilmmakers-seek-urgent-talks-pm-resuming-industry

Culture Economy Development Agency. (CENDANA) (2020a). COVID-19 impact to the arts report (Report No. 2). CENDANA. https://www.cendana.com.my/clients/Cendana_78A7CADC-1C4A-44E8-A815E2B4C1D11FE0/contentms/img/COVID/COVIDreport-29may2020.pdf

Culture Economy Development Agency. (CENDANA) (2020b). Audience propensity to return to arts activities and venues report (Report No. 4). CENDANA. https://www.cendana.com.my/clients/Cendana_78A7CADC-1C4A-44E8-A815E2B4C1D11FE0/contentms/img/Propensity\%20Report/audience-propen_46939576june12.pdf

Curtin, M., \& Sanson, K. (Eds.). (2016). Precarious creativity: Global media, local labour. University of California Press. http://dx.doi.org/10.1525/luminos.10

Dasgupta, D. (2020, April 26). Casual workers hit as Bollywood comes to a standstill amid COVID19 pandemic. The Straits Times. https://www.straitstimes.com/asia/south-asia/casualworkers-hit-as-bollywood-comes-to-a-standstill

de Peuter, G. (2011). Creative economy and labour precarity: A contested convergence. Journal of Communication Inquiry, 35(4), 417-425. http://doi.org/10.1177/0196859911416362 
Desk, N. (2020, July 17). UNIMAS Film Festival goes online. New Sarawak Tribune. https://www.newsarawaktribune.com.my/unimas-film-festival-goes-online/

El-Erian, Mohamed A. (2010). Navigating the new normal in industrial countries. International Monetary Fund.

Giardina, C. (2020, March 18). Estimated 120,000 entertainment industry crew jobs lost during pandemic. The Hollywood Reporter. https://www.hollywoodreporter.com/behindscreen/estimated-120000-iatse-jobs-lost-pandemic-1285229

Guest, P. (2020, April 1). How the coronavirus is reshaping Asia's borders, business and trade: as countries turn inward, pandemic threatens the foundations of globalisation. Nikkei Asian Review. $\quad$ https://asia.nikkei.com/Spotlight/Cover-Story/How-the-coronavirus-isreshaping-Asia-s-borders-business-and-trade

Hassandarvish, M. (2020, June 30). COVID-19: After over 100 days of closure, cinema operators in Malaysia ready to welcome back moviegoers. The Malay Mail. https://www.malaymail.com/news/showbiz/2020/06/30/COVID-19-after-over-100days-of-closure-cinema-operators-in-malaysia-ready/1880179

Hine, C. (2015). Ethnography for the internet: Embedded, embodied and everyday. Bloomsbury. HR Asia. (2017, October 27). Understanding the realities of the Malaysian freelancing economy. HR Asia. https://hrasiamedia.com/top-news/understanding-the-realities-of-themalaysian-freelancing-economy/

IndieWire Staff (2020, August 11). Coronavirus cancellations: Every film, TV show, and event affected by the outbreak. IndieWire. https://www.indiewire.com/feature/coronaviruscancellations-hollywood-entertainment-COVID19-1202215596/

Ishak, J. (n.d.). The gap in the creative industry ecosystem of Malaysia (Chapter 3 of fuelling the Kreativ Malaysia). My Creative. Retrieved December 22, 2020, from http://www.mycreative.com.my/news events/the-gap-in-the-creative-industryecosystem-of-malaysia-chapter-3-of-fuellin

Johns Hopkins University \& Medicine (n.d.). COVID-19 Dashboard by the Centre for Systems Science and Engineering (CSSE) at Johns Hopkins University and Medicine. Coronavirus Resource Centre, Johns Hopkins University \& Medicine. Retrieved May 18, 2021, from https://coronavirus.jhu.edu/map.html

Karmy, E., \& Urqueta, E. (2020, July 6). Musical workers' precarity uncovered and the revival of mutual aid in Chile. Hypotheses. https://wim.hypotheses.org/1393

Katz, B. (2020, May 21). Entertainment industry staring at $\$ 160$ B loss over 5 years due to COVID19. Observer. https://observer.com/2020/05/coronavirus-film-tv-160-billion-loss-covidpandemicl

Kay, A. (2000). Art and community development: The role the arts have in regenerating communities. Community Development Journal, 35(4), 414-424.

Khoo, K. L. (2020, May 12). Advertising filmmakers appeal to be allowed to reopen for business. The Star. $\quad$ https://www.thestar.com.my/opinion/letters/2020/05/12/advertisingfilmmakers-appeal-to-be-allowed-to-reopen-for-business

Lopez, K. A., \& Willis, D. G. (2004). Descriptive versus interpretive phenomenology: Their contributions to nursing knowledge. Qualitative Health Research, 14, 726-735.

Maganathan, D. K., \& Toh, T. (2020, April 14). Life after COVID-19: Can the show go on for Malaysia's performing arts industry? The Star. https://www.thestar.com.my/lifestyle/culture/2020/04/14/life-after-covid-19-can-theshow-go-on-for-malaysia039s-performing-arts-industry 
Malaysian National News Agency. (2020, April 8). 19th edition of French Film Festival at GSC cancelled due to MCO. BERNAMA. https://themalaysianreserve.com/2020/04/08/19thedition-of-french-film-festival-at-gsc-cancelled-due-to-mco/.

Mini Film Festival (2020a, June 16). MFF Webinar 1: Production during COVID-19 [Video]. YouTube. https://youtu.be/SK-ASZqep6k

Mini Film Festival (2020b, April 21). In case you missed out our post earlier on, the deadline for film submission have extended until 20th June, so [Image attached] [Status update]. Facebook. https://www.facebook.com/MFFunimas/photos/a.902664029801116/31211 $\underline{99804614183}$

Morgan, G., \& Nelligan, P. (2018). The creativity hoax: Precarious work in the gig economy. Anthem Press.

Omar, A. (2020, June 22). \#Showbiz: Malaysia Film Festival 2020 postponed to next year. New Straits Times. https://www.nst.com.my/lifestyle/groove/2020/06/602521/showbizmalaysia-film-festival-2020-postponed-next-year

Osman, D. (2020, March 18). In photo: Malaysia's border lockdown - before and after. Yahoo! News. https://sg.news.yahoo.com/in-photos-malaysias-border-lockdown-before-andafter-104615655.html

Pensoneau-Conway, S.L., \& Toyosaki, S. (2011). Automethodology: tracing a home for praxisoriented ethnography. Journal of Qualitative Methods, 10(4), 378-399.

Pulver, A. (2020, March 19). At least 170,000 lose jobs as film industry grinds to a halt due to coronavirus. The Guardian. https://www.theguardian.com/film/2020/mar/19/loss-ofjobs-income-film-industry-hollywood-coronavirus-pandemic-covid-19

Ramachandran, N. (2020, November 18). U.K. music industry devastated by COVID-19 impact, but outlook sunny, report says. Variety. https://variety.com/2020/music/global/uk-music-industry-coronavirus-impact-report-edsheeran-dua-lipa-1234834529/

Remesar, A. (2005). Urban regeneration: A challenge for public art (Barcelona ed.). Centre de Recerca Polis. (Original work published 1999)

Sallehudin, I. S. M. (2020a, May 14). The arts during this pandemic. The Star. https://www.thestar.com.my/news/nation/2020/05/14/the-arts-during-pandemic

Sallehudin, I. S. M. (2020b, July 21). The road ahead for the arts. The Star. https://www.thestar.com.my/lifestyle/living/2020/07/21/the-road-ahead-for-the-arts

Savage, M. (2020, November 18). Musicians will lose two-thirds of their income in 2020. BBC News. https://www.bbc.com/news/entertainment-arts-54966060

Spry, T. (2016). Body, paper, stage: Writing and performing autoethnography. Routledge.

Star (2020, August 16). Record numbers for film fest. The Star. https://www.thestar.com.my/news/education/2020/08/16/record-numbers-for-film-fest

Szalai, G. (2020, May 21). Entertainment industry's coronavirus hit estimated at $\$ 160$ billion over 5 years. The Hollywood Reporter. https://www.hollywoodreporter.com/news/entertainment-industry-coronavirus-hit-160billion-5-years-1295429

United Nations Educational, Scientific and Cultural Organisation (UNESCO) (2020, Oct 20). Call for Expression of Interest: Economic impact study of the COVID-19 on cultural and creative industries. UNESCO. https://en.unesco.org/creativity/news/call-expressioninterest-economic-impact-study-covid-19

United Nations Educational, Scientific and Cultural Organisation (UNESCO) (2017). Re-shaping Cultural Policies: Advancing Creativity for Development [2018 global report fact sheet]. 
UNESCO. https://en.unesco.org/creativity/sites/creativity/files/global_report_fact_sheet en.pdf

Vryan, K. (2006). Expanding analytic autoethnography and enhancing its potential. Journal of Contemporary Ethnography 35(4), 405-409.

Ward, C. (2020). The annihilation of time by space in the COVID-19 pandemic downturn. Dialogues in Human Geography, 10(2), 191-194.

Wayang Works (2020, May 8). Iklan raya Vivo 2020 - Behind the scenes [Video]. YouTube. https://youtu.be/2gMg-jtLpU4

Wheelock, D. C. (2020). Comparing the COVID-19 recession with the Great Depression. Economic Synopses, 39, 1-4. https://doi.org/10.20955/es.2020.39.

Wilson, J. (2020, March 20). Coronavirus: The effect on freelancers in entertainment. Forbes. https://www.forbes.com/sites/joshwilson/2020/03/20/coronavirus-the-effect-onfreelancers-in-entertainment/?sh $=6 \mathrm{~b} 724 \mathrm{fc} 93930$

Wu, W. (2004). Cultural strategies in Shanghai: regenerating cosmopolitanism in an era of globalization. Progress in Planning, 61, 159-180.

Zahiid, S. J. (2020, May 14). Excluded from CMCO, advertising film industry says daily wage workers starving. Malay Mail. https://www.malaymail.com/news/malaysia/2020/05/14/excluded-from-cmcoadvertising-film-industry-says-daily-wage-workers-starvi/1865910

i To date, there have been three instalments of MCO nationwide, respectively from March 18 till May 3, 2020, from January 13 till March 4, 2021 (except Sarawak), and from May 10 till June 6, 2021. The latter date is still subject to be extended.

ii This term first appeared in the analysis of the financial crisis in 2007-2008 (El-Erian, 2010).

iii A survey was carried out by CENDANA starting from March 19, 2020 to April 9, 2020. Among 519 participants who responded in the survey, $44 \%$ were from the performing arts sector, $33 \%$ from the music sector and $22 \%$ from the visual arts sector. As seen in the report, " $94 \%$ are either fully or partially earning an income from the arts, and $93 \%$ of this group have already been negatively impacted" (Sallehudin, 2020a).

iv A sape is a stringed musical instrument native to the Orang Ulu ethnicity in Borneo, especially the Kenyah and Kayan communities.

$\checkmark$ As of May 18, 2021, there were a total of 474,556 COVID-19 positive cases in Malaysia, while 1,947 patients have deceased (Johns Hopkins University \& Medicine, n.d.). 